\title{
PARENTAL AWARENESS OF OVERWEIGHT AND OBESITY: AN EXPLORATORY STUDY ADDRESSING LOW-INCOME ADOLESCENTS IN BRAZIL
}

\author{
Fernanda Paixão Silveira Bello ${ }^{1}$, Nathália Bordeira Chagas ${ }^{1}$, Vera Lúcia Martins Pinto ${ }^{2}$, \\ Liamaura Levy de Andrade Leite Camargo², Marcelo Marcos Piva Demarzo으, \\ Carla Maria Ramos Germano ${ }^{1}$
}

\begin{abstract}
Objective: To evaluate parental awareness and management of overweight and obesity in a sample of low income adolescents registered in a primary health care center (PHCC) in Brazil. Method: Among adolescents registered in the PHCC, 142 agreed to participate in this study and their body mass index was calculated. Unaware of the anthropometric data, parents were visited at home and asked to select a descriptor for their offspring's body weight (underweight, about right, overweight, and obese). Results: Seventeen adolescents were classified as overweight (12.0\%) and 14 as obese (10.0\%). Among 17 overweight adolescents, $13(76.5 \%)$ were accurately identified by their parents in that condition, and among 13 obese adolescents, $12(92.3 \%)$ were. Three parents of overweight $(23.1 \%)$ and five parents $(41.6 \%)$ of obese adolescents tried to manage their offspring's weight problem with a healthcare provider support. Conclusions: Despite the fact that parental recognition was relatively high in this population, our data revealed a low demand for interventionsto reverse the adolescent's overweight and obesity.
\end{abstract}

Keywords: obesity, adolescent, primary health care.

\section{INTRODUCTION}

Adolescence is a critical age for obesity development. It is well known the risk associated with obesity permanence in adulthood is higher among obese adolescents than younger children ${ }^{1,2}$. Parental inaccurate recognition of weight status is a threat to healthy weight control and could lead to a decreased emphasis in healthy eating and physical activity.Lay definitions of "overweight" and "obese" might differ from those of clinicians, and such discrepancies can present cultural and social barriers to communication between the health profession and the public.Indeed, a considerable proportion of parents fail to recognize that their children are overweight or obese ${ }^{3}$.

Early recognition of overweight and obesity can help guide interventions which could mitigate morbidity and mortalityassociated to these conditions ${ }^{4}$. Parental role is essential in preventing childhood obesity and will depend on parents' ability to recognize and manage their children's weight problems ${ }^{5}$. Health professionals should help parents develop an accurate sense of their child's body weight and future health risks resulting from overweight. Experts propose that primary healthcare providers should be responsible for detection and treatment of obese children and adolescents $^{6}$. Thus, primary care is an appropriate setting for addressing lifestyle health behaviors within a family involvement collaborative partnership?.

There are major regional and individual differences in obesity perception and natural history, which can make generalizations about this problem overly simplistic.

The aim of this study was to investigate parental awareness about adolescent's overweight

\footnotetext{
1 Department of Medicine, Federal University of São Carlos (UFSCar) - São Carlos(SP), Brazil.

2 Municipal Secretariat of Health, São Carlos (SP), Brazil.

3 Departament of Preventive Medicine, Federal University of São Paulo (UNIFESP) - São Paulo (SP), Brazil.

Corresponding author: Carla Maria Ramos Germano. E-mail: cgermano@ufscar.br.
}

Suggested citation: Bello FPS, Chagas NB, Pinto VLM, Camargo LLAL, Demarzo MMP, Germano CMR. Parental awareness of overweight and obesity: anexploratory study addressing low-income adolescents in Brazil. Journal of Human Growth and Development. 25(3): 287-291. Doi: http://dx.doi.org/10.7322/jhgd.106000

Manuscript submitted Oct 22 2014, accepted for publication Dec 192014. 
and obesity and its relation to the weight problem managing by parents in a low income population attended in a Brazilian primary health care center (PHCC).

\section{METHOD}

A cross-sectional descriptive case study was carried out to address adolescents from 10 to 18 years registered in one PHCC in the city of Sao Carlos, Sao Paulo, Brazil, 223,226 habitants. One low income PHCC was randomly chosen with a registered population of 2,268 clients from 608 families. The study was approved by the Federal University of Sao Carlos Human Research and Ethics Committee.

Demographic variables - Demographic variables included in the present analyses were age and sex.

Anthropometric data - Weight and height were measured in the PHCC setting and body mass index (BMI) was calculated as $\mathrm{kg} / \mathrm{m}^{2}$. BMI below percentile $5^{\text {th }}$ for age and sex was classified as underweight, between percentile $5^{\text {th }}$ and $85^{\text {th }}$ as normal, between $85^{\text {th }}$ and $95^{\text {th }}$ was considered overweight, and BMI at or above the percentile $95^{\text {th }}$ was considered obesity ${ }^{8}$. The adolescents were kept blind of their measures until after their parents approach.
Perceived weight - Unaware of the anthropometric data, parents were visited at home and asked to select a descriptor for their offspring's body weight from the following list: underweight, about right, overweight, and obese. The inclusion criteria were father or mother who was primary caretaker for the past two or more years ${ }^{9}$.

Managing weight by parents - Having identified a perception of overweight or obesity, parents were asked if they had managed the adolescent weight problem with a healthcare provider support (classified as "yes" or "not"). Parents were also requested to describe the weight intervention characteristics when they occurred.

Statistical analysis - Results were presented descriptively as percentage.Tables and calculations were done utilizing Microsoft Office Excel 2007.

\section{RESULTS}

Two hundred and ninety eight adolescents registered in the random $\mathrm{PHCC}$ were found. Out of that, $142(47.6 \%)$ teenagers and their parents agreed to participate in this study. Out of the 142 teenagers, 67(47.0\%) were male and 75 (53.0\%) were female. Seventeen were classified as overweight $(12.0 \%)$ and 14 as obese $(10.0 \%)$. The age, sexand BMI distribution was shown in Table 1 .

Table 1: Adolescents' demographic information and BMI category

\begin{tabular}{|c|c|c|c|}
\hline \multicolumn{2}{|c|}{ Information/Categories } & Number of Participants & $\%$ of Participants \\
\hline Sex & $\begin{array}{l}\text { Female } \\
\text { Male }\end{array}$ & $\begin{array}{l}75 \\
67\end{array}$ & $\begin{array}{l}52.8 \% \\
47.2 \%\end{array}$ \\
\hline Age & $\begin{array}{l}10-12 \\
13-15 \\
16-18\end{array}$ & $\begin{array}{l}63 \\
52 \\
27\end{array}$ & $\begin{array}{c}44.3 \% \\
36.7 \% \\
19.0\end{array}$ \\
\hline BMI & $\begin{array}{l}\text { Underweight } \\
\text { Normal } \\
\text { Overweight } \\
\text { Obese }\end{array}$ & $\begin{array}{c}6 \\
105 \\
17 \\
14\end{array}$ & $\begin{array}{l}04.1 \% \\
73.9 \% \\
12.0 \% \\
10.0 \%\end{array}$ \\
\hline
\end{tabular}

Among 17 overweight adolescents, 13 (76.5\%) were identified by their parents. Out of the 14 obese adolescents, 13 had their data collected(one family changed its home address during the study). Among 13 obese adolescents, $12(92.3 \%)$ had their weight problem identified by parents and one teenager was not considered obese (Table 2).

Table 2: Parental Awareness and Managing in Adolescents' Overweight and Obesity

$\begin{array}{lccc}\text { Category } & \begin{array}{c}\text { Total } \\ \text { number }\end{array} & \begin{array}{c}\text { \% Perceived by } \\ \text { Parents (total number) }\end{array} & \begin{array}{c}\text { \% Managed by Parents Among } \\ \text { Perceived Ones (total number) }\end{array} \\ \text { Overweight Adolescents } & 17 & 76.5 \%(13) & 23.1 \%(3) \\ \text { Obese Adolescents } & 13 & 92.3 \%(12) & 41.6 \%(5)\end{array}$

Out of parents who perceived their child as overweight or obese, three parents out of 13 (23.1\%) with overweight children and five (41.6\%) out of 12 with obese children reported that they managed their offspring's nutritional status with healthcare provider's support (Table 2). Concerning intervention characteristics, two overweight adolescent received a personalized diet prescription and the last one was oriented to reduce food ingestion and to exercise. Out of the four obese adolescents, three received a diet prescription and, the last one, a drug for weight reduction. Neither 
of them had a scheduled follow-up to evaluate weight or therapeutic adherence and outcomes.

\section{DISCUSSION}

Despite the efforts to convening all adolescents registered in the PHCC, only $47.6 \%$ appeared to participate in the present study. This lack of interest of young people in a medical assessment has been suggested in the literature even in a primary health care setting ${ }^{10}$. Based on this small sample size, either more in-depth qualitative work would be needed regarding reasons for perceptions or barriers to weight management interventions, or more sites should be assessed to provide a larger sample size. On the other hand, the prevalence of overweight and obesity observed in our convenient sample study is similar to that described worldwide ${ }^{11}$. We found a higher prevalence of overweight and obesity in female adolescents compared to males, which is consistent with data previous described in Brazil'12,13.

Regarding parent's perception about overweight and obesity, the tendency to underestimate children's overweight problems has been described in the literature ${ }^{14}$. For example, two previous studies showed that about $54-55 \%$ of parents had an inadequate perception of their children's weight ${ }^{15,16}$. Surprisingly, we found that a much higher percentage of parents were aware of their adolescents' overweight problems compared to previous data. One possibility is that those adolescents' families who agreed to participate in our study were already worried about their weight condition, a bias of selection inherent to case studies. Others hypothesis are that it would be easier to identify a weight problem in an adolescent compared to children, and/oralso the existence of cultural differences inherent to Brazilian parents. Future qualitative studies may better clarify this finding.

Our data revealed a low index of parental and healthcare center interventions to reverse overweight and obesity in the studied adolescent sample as described by Huang et $a /^{17}$ in US. This was expected according to previous data which pointed out that childhood overweight and obesity treatment wasoverall neglected by their families and physicians ${ }^{18}$. It is interesting to notice that the families were aware of the weight problem, but this was not always followed up by a search for health assessment and therapeutic intervention.

Furthermore, the primary healthcare team studied did not act effectively in the prevention and treatment of adolescence weight problems as they were expected to ${ }^{19}$. Similar to our findings, BENSON and colleagues ${ }^{20}$ analyzed electronic medical recorded data and concluded that a large percentage of overweight and obese patients remained undiagnosed by the health professional ${ }^{20}$. Various barriers to identify and treat pediatric overweight have been pointed out in previous studies and could be occurring in our sample: healthcare professionals' inappropriate perception of body size and weight status ${ }^{21}$, lack of training in behavioral management strategies and parenting techniques, no commitment to dealing with the social causes ${ }^{22,23}$ and perception that there are significant barriers to patient and family compliance with advice ${ }^{18}$. GPs preference to referring to the problem to specialized services in some situations was also reported ${ }^{24}$. On the other hand, chart review could not be the best way to identify recognition and management of obesity by physicians. Physicians may recognize obesity and even provide counseling, but may not document this in charts for a number of reasons. Furthermore, in environments with high rates of obesity, physicians could feel that it is futile to document obesity even though they fully recognize the problem.

It has been difficult to help adolescents successfully lose weight and maintain weight loss, even when there is awareness of the problem ${ }^{25}$. Parental and primary care teams' involvement in this effort is fundamental. Various demographic factors and personal perceptions are associated with parents and health professionals' readiness to help adolescents lose weight. Knowledge of these factors may be beneficial to providers and program developers when addressing pediatric overweight and obesity and initiating new interventions ${ }^{25}$.

Although the results of this may not be generalized for the Brazilian population and it is limited by a small sample size and confined to one city and socioeconomic stratum, this study address a key issue poorly investigated in Brazil and in the world as well.These findings may be particularly important for clinicians and public health policymakers who probably should go beyond awareness promotion, addressing also possible behavior and cultural factors related to effective health habitmodification in this population ${ }^{26,27}$. Moreover, as suggested by Boothet $a^{28}$, health professionals rather than simply labeling children as overweight or obese should be more effective by focusing on shared goals with parents.

\section{CONCLUSION}

Despite the fact that parental recognition of their springs' nutritional status was relatively high in this population, our data revealed a low demand for interventions to reverse the adolescent's overweight and obesity.

Our findings may influence new and larger studies in the issue, focused upon parental perception of adolescents' weight in low-income communities. In addition, our data may help health managers and professionals to design programs that not only draw attention to the weight problem itself, but also provide a better strategy to address the perception of this issue among patients, parents, and health professionals involved in this prevalent and important public health issue. 


\section{REFERENCES}

1. Monasta L, Batty GD, Cattaneo A, Lutje V, Ronfani L,Van Lenthe FJ, et al. Early-life determinants of overweightand obesity: a review of systematic reviews. Obes Rev 2010; 11(10): 695-708. DOI: http://dx.doi.org/ 10.1111/j.1467-789X.2010.00735.x

2. Conde WL, Borges C. O risco de incidência e persistência da obesidade entre adultos brasileiros segundo seu estado nutricional ao final da adolescência. Rev Bras Epidemiol. 2011; 14(Supl 1):71-9. DOI: http://dx.doi.org/ 10.1590/S1415-790X2011000500008

3. Zeller M, Daniels S. The obesity epidemic: family matters. J Pediatr. 2004;145(1): 3-4. DOI: http://dx.doi.org/10.1016/j.jpeds. 2004. 04.038

4. Francescatto C, Santos NS, Coutinho VF, Costa RF. Mothers' perceptions about the nutritional status of their overweight children: a systematic review. J Pediatr (Rio J). 2014;90(4): 332-43. DOI: http://dx.doi.org/10.1016/j.jped.2014. 01.009

5. Garbutt JM, Leege E, Sterkel R, Gentry S, Wallendorf $M$, Strunk RC. What are parents worried about? Health problems and health concerns for children. Clin Pediatr. 2012;51(9): 840-7. DOI: http://dx.doi.org/10.1177/00099 22812455093

6. Medeiros CCM, Cardoso MAA, Pereira RAR, Alves GTA, França ISX, Coura AS, et al. Estado nutricional e hábitos de vida em escolares. Rev Bras Crescimento Desenvolv Hum. 2011; 21(3): 789-97.

7. Akerman A, Williams ME, Meunier J. Perception versus reality: an exploration of children's measured body mass in relation to caregivers' estimates. J Health Psychol. 2007;12(6): 871-882. DOI: http://dx.doi.org/10.1177/ 1359105307082449

8. Katzmarzyk PT, Barlow S, Bouchard C, Catalano $\mathrm{PM}$, Hsia DS, Inge $\mathrm{TH}$, et al. An evolving scientific basis for the prevention and treatment of pediatric obesity. Int J Obes (Lond). 2014;38(7):887-905. DOI: http://dx.doi.org/ 10.1038/ijo.2014.49

9. Wald ER, Ewing L, Cluss P, Goldstrohm S, Cipriani L, Colborn K. Establishing a familybased intervention for overweight children in pediatric practice. Ann Fam Med. 2005;3(Suppl 2):S45-7. DOI: http://dx.doi.org/10.1370/ afm.366

10. Santiprabhob J, Leewanun C, Limprayoon $K_{\text {, }}$ Kiattisakthavee $\mathrm{P}$, Wongarn $\mathrm{R}$, Aanpreung $\mathrm{P}$, et al. Outcomes of group-based treatment program with parental involvement for the management of childhood and adolescent obesity. Patient Educ Couns. 2014;97(1):6774. DOI: http://dx.doi.org/10.1016/j.pec. 2014.07.002

11. Centers for Disease Control and Prevention (CDC). BMI for children and teens. [cited 2015Sep23] Available from:http://www. cdc.gov/nccdphp/dnpa/bmi/bmi-for-age. htm.
12. Oliveira AMA, Cerqueira EMM, Oliveira AC.Prevalência de sobrepeso e obesidade infantil na cidade de Feira de Santana-BA: detecção na família $x$ diagnóstico clínico. J Pediatr. 2003;79(4):325-8. DOI: http:// dx.doi.org/10.1590/S0021-75572003000 400010

13. Tyler S, Mayhew-Stokes C, Jackson E. Engaging with pre-teens and their parents in primary care. J Fam Plann Reprod Health Care. 2009;35(1):38-40. DOI: http://dx.doi.org/ 10.1783/147118909787072388

14. Gupta N, Goel K, Shah P, Misra A. Childhood Obesity in Developing Countries: Epidemiology, Determinants, and Prevention. Endocr Rev. 2012;33(1):48-70. DOI: http://dx.doi.org/ 10.1210/er.2010-0028

15. Niehues JR, Gonzales AI, Lemos RR, Bezerra PP, Haas P. Prevalence of overweight and obesity in children and adolescents from the age range of 2 to 19 years old in Brazil. Int J Pediatr. 2014;(2014): 7. DOI: http://dx.doi.org/ $10.1155 / 2014 / 583207$

16. Jeffery AN, Voss LD, Metcalf BS. Parents' awareness of overweight in themselves and their children: cross sectional study within a cohort(EarlyBird 21).BMJ. 2004;330(7481): 23-4. DOI: http://dx.doi.org/10.1136/bmj. 38315.451539.F7

17. Huang TT, Borowski LA, Liu B, Galuska DA, Ballard-Barbash R, Yanovski SZ, et al. Pediatricians' and family physicians' weightrelated care of children in the U.S. Am J Prev Med. 2011;41(1):24-32. DOI: http:// dx.doi.org/10.1016/j.amepre.2011.03.016

18. Banks J, Shield JP, Sharp D. Barriers engaging families and GPs in childhood weight management strategies. Br J Gen Pract. 2011;61(589):e492-7. DOI: http://dx.doi.org/ 10.3399/bjgp11X588466

19. van Gerwen M, Franc C, Rosman S, Le Vaillant M, Pelletier-Fleury N. Primary care physicians' knowledge, attitudes, beliefs and practices regarding childhood obesity: a systematic review. Obes Rev. 2009;10(2):227-36. DOI: http://dx.doi.org/10.1111/j.1467789X.2008.00532.x

20. Benson L, Baer HJ, Kaelber DC. Trends in the diagnosis of overweight and obesity in children and adolescents: 1999-2007. Pediatrics. 2009;123(1):e153-8. DOI: http://dx.doi.org/ 10.1542/peds.2008-1408

21. Patel AI, Madsen KA, Maselli JH, Cabana MD, Stafford RS, Hersh AL. Underdiagnosis of pediatric obesity during outpatient preventive care visits. Acad Pediatr. 2010;10(6):405-9. DOI: http://dx.doi.org/10.1016/j.acap.2010. 09.004

22. Michie S. Talking to primary care patients about weight: a study of GPs and practice nurses in the UK. Psychol Health Med. 2007;12(5):5215. DOI: http://dx.doi.org/10.1080/135485007 01203441 
23. Wofford LG. Systematic review of childhood obesity prevention. J Pediatr Nurs. 2008; 23(1): 5-19. DOI: http://dx.doi.org/10.1016/j.pedn. 2007.07.006

24. King LA, Loss JHM, Wilkenfeld RL, et al. Australian GPs' perceptions about child and adolescent overweight and obesity: the Weight of Opinion study. Br J Gen Pract. 2007; 57(535): 124-9.

25. Yi-Frazier JP, Larison C, Neff JM, Grow HM, Liu LL. Obesity in pediatric specialty clinics: an underestimated comorbidity. Clin Pediatr. 2012; 51(11): 1056-62. DOI: http://dx.doi.org/10. $1177 / 0009922812458353$

26. Franzini L, Elliott MN, Cuccaro P, Schuster $M$, GillilandMJ, Grunbaum JA, et al. Influences of physical and social neighborhood environments on children's physical activity and obesity. Am J Public Health. 2009;99(2):271-8. DOI: http:/ /dx.doi.org/10.2105/AJPH.2007.128702

27. Smith KL, Straker LM, McManus A, Fenner AA. Barriers and enablers for participation in healthy lifestyle programs by adolescents who are overweight: a qualitative study of the opinions of adolescents, their parents and community stakeholders. BMC Pediatr. 2014;14:53. DOI: http://dx.doi.org/10.1186/1471-2431-14-53

28. Booth ML, Wilkenfeld RL, Pagnini DL, Booth $S L$, King LA. Perceptions of adolescents on overweight and obesity: the weight of opinion study. J Paediatr Child Health. 2008;44(5):24852. DOI: http://dx.doi.org/10.1111/j.14401754.2007.01267.x

\section{Resumo}

Objetivo: Avaliar o reconhecimento e o manejo por parte dos pais frente a situações de sobrepeso e obesidade de adolescentes. Método: Entre os adolescentes de baixa renda cadastrados em um centro de atenção primária à saúde no Brasil, 142 tiveram seu índice de massa corporal calculado. Sem terem conhecimento dos dados antropométricos, os pais foram solicitados a selecionar um descritor para o peso corporal de seus filhos (baixo peso, peso adequado, sobrepeso e obeso). Resultados: Dezessete adolescentes foram classificados como sobrepeso (12.0\%) e 14 como obesos $(10.0 \%)$. Entre os 17 adolescentes com sobrepeso, $13(76.5 \%)$ foram corretamente identificados por seus pais e, entre 13 adolescentes obesos, 12 (92.3\%) foram identificados como tal. Três pais de adolescentes com sobrepeso $(23.1 \%)$ e cinco pais $(41.6 \%)$ de adolescentes obesos procuraram a ajuda de um profissional de saúde para tratarem o problema de peso de seus filhos. Conclusões: O reconhecimento dos pais foi relativamente alto, porém, houve uma baixa demanda por intervenções que pudessem reverter o sobrepeso e a obesidade dos adolescentes.

Palavras-chave: obesidade, adolescente, atenção primária à saúde. 